\title{
NICERGOLINE IN THE TREATMENT OF NEUROPATHIC BLADDER DYSFUNCTION: A PRELIMINARY REPORT
}

\author{
By J. Gallego, M.D., V. Forner, M.D., D.Phys.Med., F. Jimenez, M.D. \\ and E. MARTINEZ, M.D. \\ Spinal Unit, Division of Urology and Rehabilitation, 'La Fe', Valencia, Spain.
}

Summary. We have employed the alpha blocking drug Nicergoline in I 4 patients with neuropathic bladder dysfunction of the upper motor neurone type.

The oral administration of I 5-30 mgrs/day of this drug over a period of 9.5 months significantly improved the urodynamic parameters, with an increase of bladder capacity, a disappearance or amelioration of uninhibited bladder contractions and a decrease in urethral pressure, profile urethral length and residual urine.

Two patients with vesico-ureteral reflux present before treatment showed radiological improvement after Nicergoline administration.

Tolerance of Nicergoline had been excellent without appreciable side effects. In conclusion, Nicergoline seems to be active and well tolerated in the pharmacological treatment of neuropathic bladder dysfunction.

Key words: Paraplegia; Neuropathic bladder; Nicergoline; Alpha blocking agents.

\section{Introduction}

IT is well known that the alpha-adrenergic blocking agents are effective in the treatment of the neurogenic bladder (Hachen, I980; Mobley, I976). They also produce a relaxing effect on the urethral smooth muscle (Donker et al., I972; Whitfield et al., I976), and also reduce the detrusor hyperactivity (Kaplan and Nanninga, I979). Until now other drugs have been used, especially phenoxybenzamine hydrochloride, which is effective but is not commercially available in our country. It also has some undesirable side effects.

For the reasons mentioned above we have used in patients with a neuropathic bladder the ergoline derivative Nicergoline, which is widely used as vasodilator (Boismare et al., I98I; Pony et al., I982), and is remarkably free of side-effects. Recently, Nicergoline has been used by Ronchi et al. (I982) in prostatic patients with encouraging results and good tolerance.

\section{Material and Methods}

Fourteen patients with a neuropathic bladder after spinal cord lesion were included in this study. The neurological deficit was complete in eight patients (six paraplegics and two tetraplegics), and incomplete in six. All patients had passed the stage of spinal shock at the time of the study, which was carried out between 6 months and 12 years after the accident, the average time being of 3.7 years.

The age of the patients ranged from I2-60 years, with a mean age of 37 years. All had unbalanced upper motor neurone bladders with high residual urine. None had been previously treated with alpha blockers. Eleven patients were completely incontinent (using a condom urinal) and 
three patients were continent, although with some voiding disturbance.

Urodynamic and radiological investigations were performed in all the patients before beginning the treatment.

The urodynamic investigations were carried out using a multichannel apparatus which allows simultaneous recordings of bladder and rectal pressure and external sphincter electromyography. A urethral pressure profile was performed after these simultaneous recordings according to the Brown-Wickham method (Brown and Wickham, I969).

The bladder pressure was measured with a 12 Foley catheter, using a slow filling rate of $20 \mathrm{ml} / \mathrm{min}$ and abdominal pressure was recorded by means of a flaccid balloon filled with $\mathrm{I} 0 \mathrm{ml}$ water. We have not used the electronic method of subtracting intrarectal pressure from intravesical pressure in order to obtain a better recording of uninhibited bladder contractions. The sphincter electromyography was performed using two wire electrodes inserted into the perineum in the vicinity of the prostatic apex. The neutral electrode was placed on the skin of the thigh.

The functional profile length was estimated according to the International Continence Society as the length of the urethra in which the urethral pressure exceeds bladder pressure (Bates et al., I977).

The radiological study included an I.V.P. and retrograde cystography.

After this initial evaluation the treatment with Nicergoline was started, being administered orally at a daily dosage of $15 \mathrm{mg}$ in three divided doses. During the treatment the residual urine was checked daily and twice a day also the blood pressure. The appearance of the possible side effects of an alpha-adrenolytic therapy (nasal congestion, lethargy, dizziness, postural hypotension, etc.), was carefully observed.

After I5 days of treatment all the patients were urodynamically reassessed but radiological examinations were only carried out in cases with abnormalities at the initial evaluation.

The objective criteria of response were a decrease in residual urine (higher than a Io per cent of bladder capacity), urodynamic improvement and radiological amelioration. In three patients with incomplete lesions and spontaneous voiding we also considered subjective criteria of improvement in the micturition pattern.

In the event of good response the treatment was continued with the same dosage. If the response was incomplete or poor the dosage was increased to $30 \mathrm{mg} /$ day and a new evaluation was performed after I 5 days of the 'high dosage regime'. If the higher dosage proved to be effective the administration of Nicergoline was continued at $30 \mathrm{mg} /$ day. When there was lack of therapeutic response to this high dose regime of Nicergoline we tended to change to another alpha blocking agent or to consider a surgical intervention (transurethral sphincterotomy). differences.

Statistical analysis were made using the Wilcoxon rank test for paired

\section{Results}

All I 4 patients completed the trial. The I $5 \mathrm{mg} /$ day dosage was sufficient in ten but in four it was necessary to increase the dose to $30 \mathrm{mg} / \mathrm{day}$.

Tolerance has been excellent without side effects. Only one patient with an incomplete lesion complained of anejaculation, possibly due to 
TABLE I

Urodynamic parameters before and after Nicergoline administration

\begin{tabular}{lccccc}
\hline & $\begin{array}{c}\text { Bladder } \\
\text { capacity }\end{array}$ & $\begin{array}{c}\text { Maximum } \\
\text { intravesical } \\
\text { pressure } \\
\left(\mathrm{cm} \mathrm{H} \mathrm{H}_{2} \mathrm{O}\right)\end{array}$ & $\begin{array}{c}\text { Residual } \\
\text { urine } \\
(\mathrm{cc})\end{array}$ & $\begin{array}{c}\text { Urethral } \\
\text { pressure } \\
\left(\mathrm{cm} \mathrm{H}_{2} \mathrm{O}\right)\end{array}$ & $\begin{array}{c}\text { Profile } \\
\text { length }\end{array}$ \\
$(\mathrm{cm})$
\end{tabular}

absence of emission, a known side effect of the alpha blocking drugs on the seminal tract (Hachen, I980).

The duration of treatment ranged from 6-I2 months, with an average time of 9.5 months. It was not considered necessary in any case to change to another alpha blocking agent or to perform an operation.

The urodynamic parameters before and after Nicergoline administration are shown in Table I and Figures I and 2.

The bladder capacity increased in nine patients and remained unchanged in five, the average increase being 34.26 per cent $(p<0.05)$.

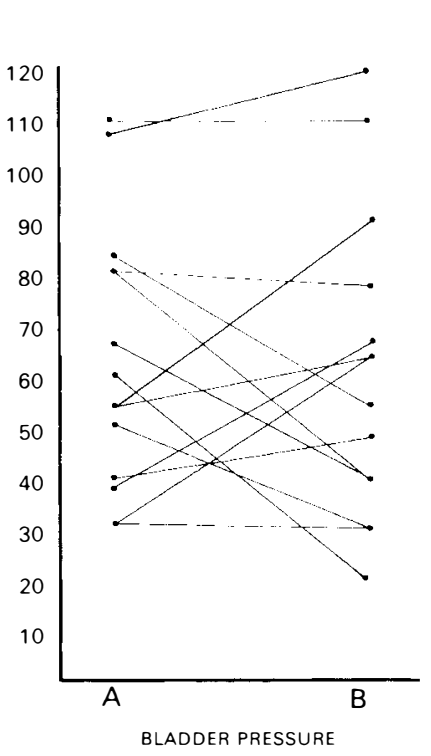

N.S

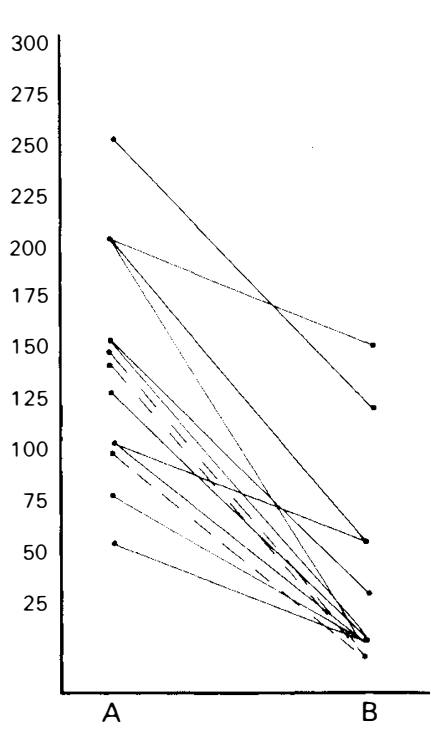

RESIDUAL URINE

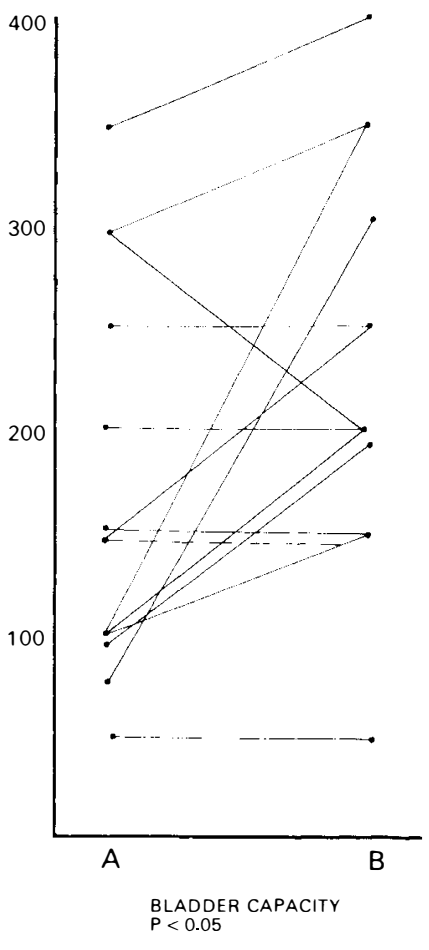

FIG. I

Urodynamic parameters before (A) and after (B) Nicergoline administration. Bladder. Residual urine and bladder capacity: cc. Bladder pressure: $\mathrm{cm}_{2} \mathrm{O}$. N.S.: no significant differences. The discontinuous line means equal values in different patient. 

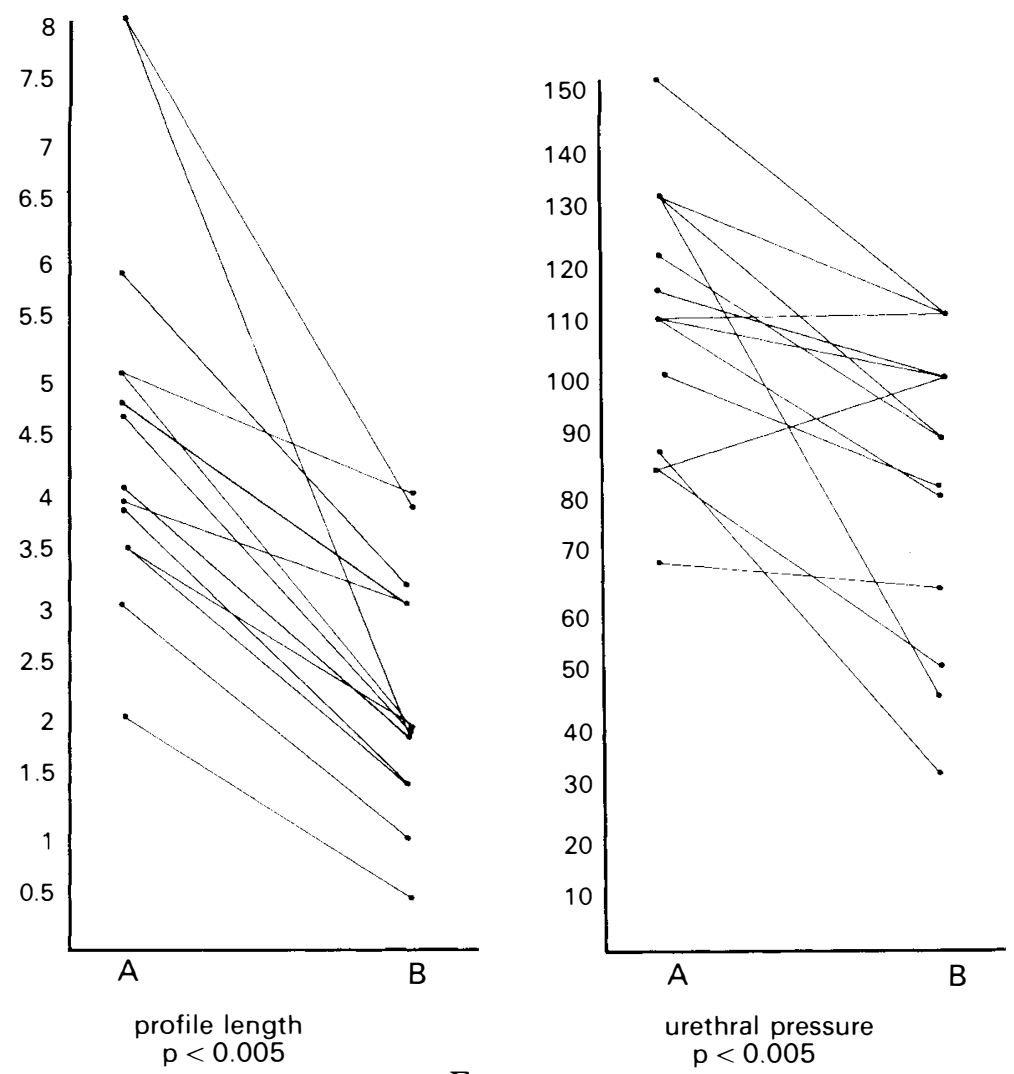

FIG. 2

Urodynamic parameters before and after Nicergoline. Urethra.

Residual urine decreased in all the patients, with an average decrease of $8 \mathrm{I} \cdot 37$ per cent in relation to the initial mean value $(\mathrm{p}<0.005)$. In relation to bladder capacity the residual urine at the start of treatment was 78.65 per cent of bladder capacity, decreasing to I I 05 per cent of bladder capacity after Nicergoline administration.

The urethral pressure decreased in 13 patients. The reduction was 20.65 per cent of the initial mean value $(\mathrm{p}<0.005)$ and the profile functional length decreased in all the patients, about $49 \cdot 78$ per cent of the initial mean values $(\mathrm{p}<0.005)$.

No significant changes were found in maximal intravesical pressure. Detrusor waves were present in four patients, disappearing in three after Nicergoline administration. The vesico-sphincter dyssynergia (diagnosed through the simultaneous pressure/electromyography recordings in II patients), disappeared in six cases after treatment. The variable response of the striated sphincter is possibly due to the doubtful role of alpha receptors in this area (Rossier et al., I982).

The micturition pattern was tested in three patients with incomplete lesions and spontaneous voiding and all reported improvement in frequency and urgency.

Radiological alterations were found in two patients. 


\section{Case I}

A 28-year-old man was admitted with an incomplete spinal lesion below Th5 due to a casual accident 4 years before.

He complained of frequency and urgency of micturition and had had recurrent episodes of acute pyelonephritis. The urodynamic study showed a bladder capacity of $100 \mathrm{cc}$, multiple detrusor waves and a residual urine of $50 \mathrm{cc}$. The urethral pressure was I IO $\mathrm{cm} \mathrm{H}_{2} \mathrm{O}$ and the profile length $5 \mathrm{~cm}$.

The IVP showed right ureteropyelo-caliectasis (Fig. 3A) and the voiding cystogram right vesico-ureteral reflux grade IIb. After Nicergoline administration ( $15 \mathrm{mg} /$ day) the voiding symptoms improved and the urodynamic investigation showed increased bladder capacity $(200 \mathrm{cc})$, a decrease in urethral pressure $\left(80 \mathrm{~cm} \mathrm{H}_{2} \mathrm{O}\right)$ and a decrease in profile length $(3 \mathrm{~cm})$. The IVP demonstrated marked improvement of the right ureteropyelo-caliectasis (Fig. 3B), although the vesico-ureteral reflux was still present in the voiding cysto-urethrogram. The persistence of the reflux is considered secondary to extra-vesicalisation of the intramural ureter as shown in Fig. 3B; however, we think that an antireflux operation is not necessary as the IVP remains improved and the pyelonephritic attacks have disappeared during the twelve months of treatment.

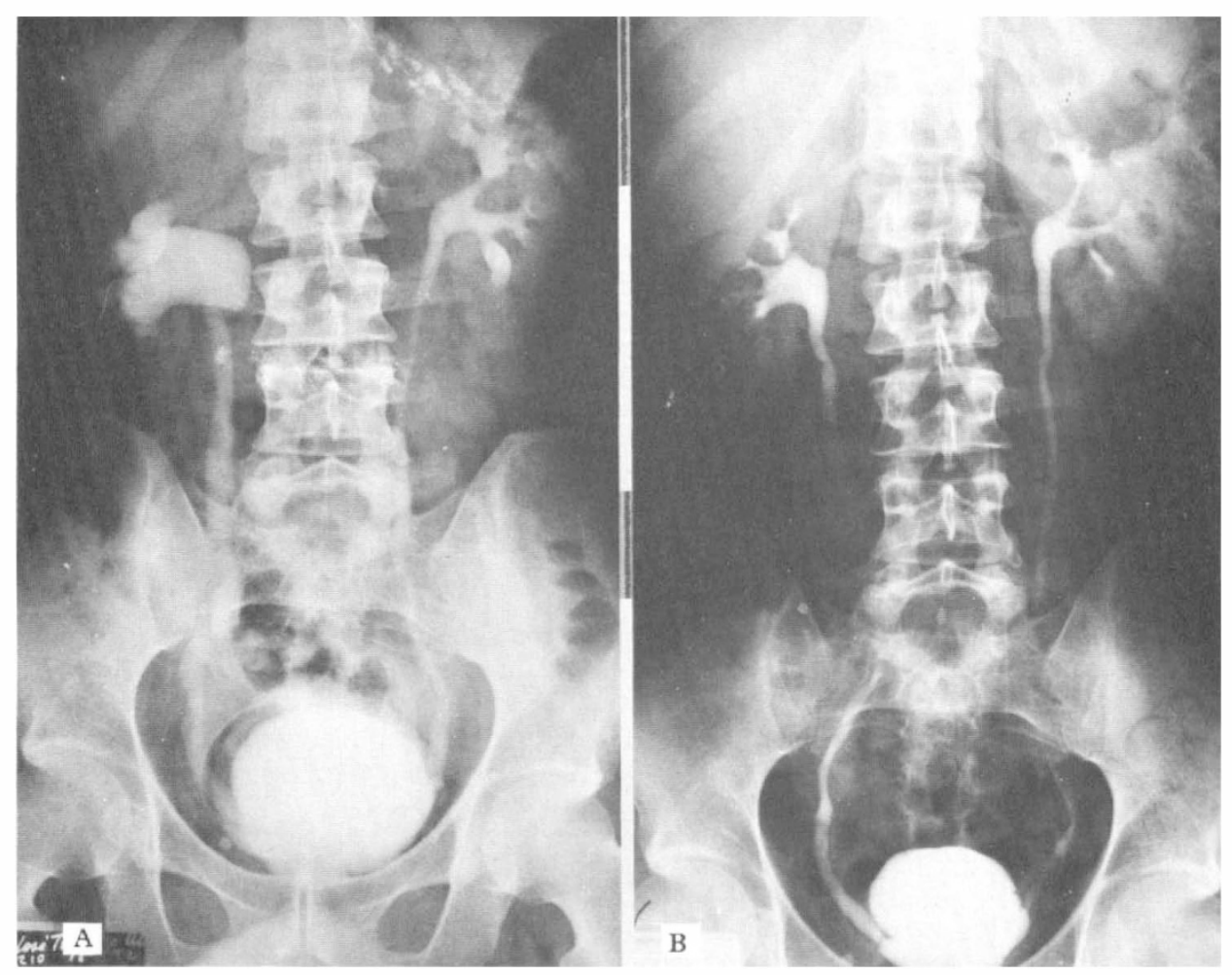

FIG. 3

Case number I I.V.P. at ro minutes. (A) Before treatment. Right ureteropyelocaliectasis. (B) After treatment, showing marked improvement of right ureteropyelogram. 


\section{Case 2}

A 50-year-old man, with an incomplete paraplegia below Thi2, was admitted with a recent onset of episodes of fever, pyuria and left flank discomfort. Urine culture yielded more than I00.000 colonies per cc of $E$. coli but was sterilised by antibiotic therapy.

The urodynamic investigation showed a bladder capacity of I $50 \mathrm{cc}$, a reflex bladder contraction of $54 \mathrm{~cm} \mathrm{H}_{2} \mathrm{O}$ of pressure and vesicosphincter dyssynergia. Urethral pressure was I IO $\mathrm{cm} \mathrm{H} \mathrm{H}_{2} \mathrm{O}$, profile length $3.5 \mathrm{~cm}$ and residual urine IOO cc. The IVP was within normal limits but in the retrograde cystogram a left grade IIb vesico ureteral reflux, with a contracted bladder, was found (Fig. 4A).

Nicergoline was administered at a dose of $15 \mathrm{mgr} /$ day without any significant improvement. When the dose was increased to $30 \mathrm{mgr} / \mathrm{day}$, however, the urodynamic parameters improved, with disappearance of vesicosphincter dyssynergia. The residual urine was abolished, the urethral pressure fell to $84 \mathrm{~cm} \mathrm{H}_{2} \mathrm{O}$ and the profile length shortened to $\mathrm{I} \mathrm{cm}$. The retrograde cystogram demonstrated absence of reflux and disappearance of bladder wall trabeculation (Fig. 4B). The treatment continued for 12 months without recurrence of pyelonephritis.
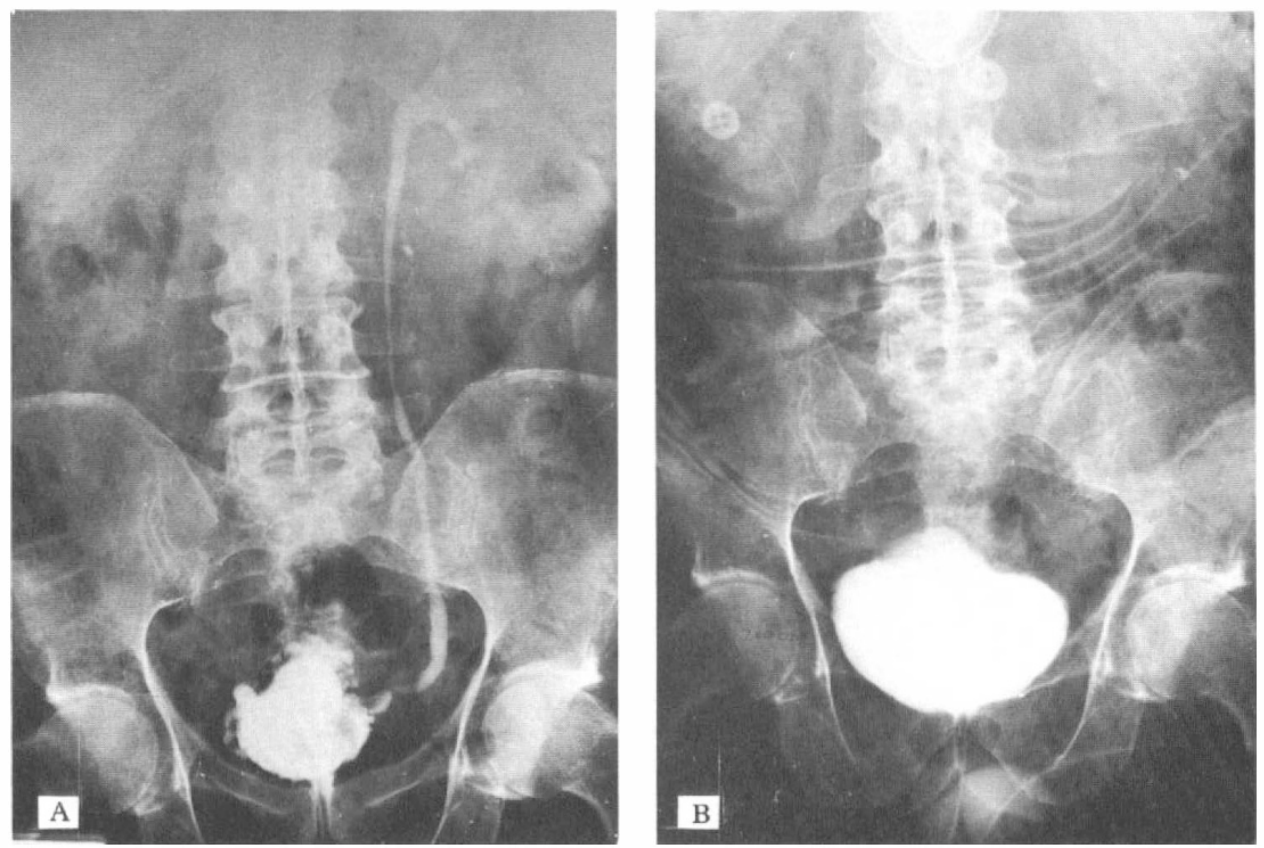

FIG. 4

Case number 2. Retrograde cystography. (A) Before treatment. Bladder wall trabeculation and left vesicoureteral reflux grade IIb. (B) After treatment. Vesicoureteral reflux has
disappeared, and the bladder wall is smooth. Both films are made with I $50 \mathrm{cc}$ of contrast media. 


\section{Discussion}

The presence of adrenergic receptors in the human lower urinary tract has been demonstrated both in the outflow region (Awad et al., 1974) and in the prostate (Caine et al., 1975). The pharmacological blockade with phentolamine of the alpha receptors causes a relaxation of the urethral smooth muscle fibres, with decrease in urethral pressure and urethral profile length (Donker et al., 1972; Whitfield et al., 1976). These effects are more evident in patients with a neuropathic bladder than in normal individuals (Rossier et al., 1982), possibly due to an urethral hypersensitivity to alpha stimulation when bladder denervation is present. Koyanagi (I982) report an increase in blood catecholamines in patients with lower motor neurone lesions when placed in the sitting position, leading to an 'urethral sympathetic dyssynergia' that causes outflow obstruction in response to this postural discharge of catecholamines (Koyanagi et al., I982).

Nevertheless, Nordling, in histochemical studies of trigonal and bladder strips obtained from patients with neuropathic bladder, failed to demonstrate an increment in adrenergic fibres as an organic basis for urethral hypersensitivity (Nordling et al., I980).

From a clinical point of view the alpha blocking agents are being used increasingly in the management of the outflow urinary obstruction, both in neuropathic bladder (Hachen, I980; Scott, 1978) and in prostatism (Caine et al., I976). The drug most commonly used is phenoxybenzamine hydrochloride, which causes urethral relaxation similar to phentolamine with the advantage of oral administration, thus allowing long term treatment. Furthermore, the bladder hyperreflexia improves with phenoxybenzamine by direct inhibition of the alpha receptors of the bladder and outflow region (Khanna, 1976), or by blocking the transmission in the parasympathetic ganglia surrounding the bladder (Rossier et al., I982). Scott et al. (1978) reported improvement in autonomic dysrreflexia with phenoxybenzamine but only if the drug is used previously to the stimulus (Scott et al., I978).

The dose of phenoxybenzamine varies between 10-30 mgr/day, seldom more (Mobley, I976). Several authors (Hachen, I980; Scott, 1978) report better results in lower motor neurone lesions, probably due to the urethral denervation hypersensitivity, while others (Mobley, 1976) report better results in reflex bladders.

Phenoxybenzamine has some side effects, including postural hypotension, nasal congestion, dizziness, tiredness and lethargy, which make it necessary to discontinue its administration in a 2.6 per cent-I 6 per cent of patients (Mobley, 1976; Scott, 1978). In order to obtain the same benefits of phenoxybenzamine without its side effects other alpha adrenergic blockers have been used.

Hence, Prazosin, a selective alpha I adrenergic blocking agent with less side effects, has a documented action on the urethra (Kiruluta et al., I98I), and has been employed by Jensen with good results in four out of five patients with uninhibited bladder (Jensen, I98I).

Another drug investigated has been Thymoxamine (Pedersen et al., 1980), which decreases urethral pressure and uninhibited bladder contractions thirty minutes after intravenous administration of $\mathrm{O} \cdot \mathrm{I} \mathrm{mgr} / \mathrm{day}$. Nevertheless, Thymoxamine has not been used in a prolonged course of treatment. 
Nicergoline is an ergoline derivative with alpha blocking activity (Arcari et al., I972) successfully used as vasodilating agent (Boismare et al., I98I; Pony et al., I982), in vascular retinopathies (Bec et al., I976), and as an inhibitor of platelet aggregation (Migne et al., I974) with good tolerance in each case. Recently, Ronchi et al. (I982) have employed Nicergoline in patients with prostatism and report a good subjective and objective response (an increase in urinary flow), after a 3-day course or treatment with $4 \mathrm{mgr}$ by intramuscular injection twice a day (Ronchi et al., I982).

The remarkable lack of side effects has encouraged us to use Nicergoline as an alpha adrenergic blocking agent in the management of neuropathic bladder, and, according to our experience, the first results are encouraging with regard to effectiveness and tolerance. It can be administered orally at a daily dose of I 5-30 mgr.

We shall continue our study in order to obtain experience with more patients for longer periods and the long term results will be assessed.

\section{Conclusions}

I. Nicergoline, an alpha adrenergic blocking agent, is effective in the treatment of neuropathic bladder.

2. This drug is very well tolerated.

3. We consider that this drug deserves further investigation.

\section{RÉSUMÉ}

On a utilisé l'alpha-bloquéant Nicergoline sur quatorze patients atteints de dysfonctionnement vésical neurogenique. On a employé une dose de I5-30 mg par jour, voie orale, pendant 9.5 mois.

On a constaté une amélioration urodynamique dans tous les patients, la diminution du résidu postmictionnel, l'augmentation de la capacité vésicale et la disparition ou diminution des contractions vésicales non inhibées. On a objectivé aussi la réduction de la pression urétrale de fermeture et de la longueur fonctionnelle due profil urétral.

Aprés l'administration de Nicergoline, on a eu une amélioration radiologique dans deux cas de reflux vésico urétéral.

La tolérance a été excellente, sans effets secondaires.

Enfin, nous croyons que la Nicergoline est un alpha-bloquéant actif et bien toléré dans le traitement de la neurovessie.

\section{ZUSAMMENFASSUNG}

Wir haven das alfa blockierende Nicergoline bei I4 Patienten mit neurogenen Störungen der Blasse eingesetzt. Die benutzte Dosis war I 5-30 mgr. täglich, auf oralen Wege verabreicht, bei einer Durchschnittszeit von 9.5 Menaten.

Es konnte eine Besserung der Blasenfunktion in allen Fällen festgestellt werden, einhergehend mit einer Verminderung der Urinrückhaltung, Zunahme der Blasenkapazität und ein Verschwinden oder Zurückgehen der Blasenkontraktionen. Gleichzeitig konnte ein Abbau des Drucks des Harnröhrenverschlusses und ein Rückgang in der funktionellen Länge des Umrisses der Harnröhe festgestellt werden.

In zwei Fällen von Harnrückflüssen konnte radiologisch eine Besserung festgestellt werden, nach der Einnahme von Nicergoline.

Die Verträglichkeit war ausgezeichnet ohne Anzeichen von sekundären Störungen.

Zusammenfassend: Wir glauben, das Nicergoline als ein aktiver und gut verträglicher Alpha-Blocker bei der Behandlung der Blasenströrungen angebracht erscheint. 


\section{REFERENCES}

Arcari, G., Bernardi, L., Bosisio, G., Coda, S. Fregnan, B. \& Glasser, A. H. (i972). Io alpha methoxyergoline derivatives as alpha adrenergic blocking agents. Experientia, 28, 319-320.

Awad, S. A., Pruce, A. W., Carro-Ciampi, G., Downie, J. W., Lin, M. \& Marks, G. S. (1974). Distribution of alpha and beta adrenoceptors in human urinary bladder. $\mathrm{Br}$. f. Pharmacol., 50, 525-529.

Bates, P., Bradley, W. E., Glen, E., Melchior, H., Rowan, D., Sterling, A. \& Hald, T. (1977). First report on the standardization of terminology of lower urinary tract function. Urol. Int., 32, 8I-87.

Bec, P., Doly, N. \& ARne, J. L. (I976). Etude de l'action de la Nicergoline en ophtalmologie. Gaz. Med. France, 83, 2 I I9-2 22.

Boismare, F., Leclerc, J. L., Lefrancois, J., Moore, N., Paux, G., Schrub, J. C. \& VuILlERMET, P. (I98I). Effets hémodynamiques et métaboliques de l'epreuve d'effort chez l'arteritique diabètique traté ou non par la Nicergoline. Sem. Hop. Paris, 57, I $455-1457$.

Brown, W. \& Whiскнам, J. E. A. (I969). The urethral pressure profile. Br. F. Urol., 4I, 2 I I-2 I 7 .

Caine, M., RAZ, S. \& Zeigler, M. (1975). Adrenergic and cholinergic receptors in the human prostate, prostatic capsule and bladder neck. Br. F. Urol., 47, 193-202.

Caine, M., Pfau, A. \& Perlberg, S. (1976). The use of alpha adrenergic blockers in benign prostatic obstruction. Br. F. Urol., 48, 255-263.

Donker, P. J., Ivanovici, F. \& Noach, E. L. (1972). Analyses of the urethral pressure profile by means of electromyography and the administration of drugs. Br. F. Urol., 44, I80-I 93 .

HACHEN, H. J. (I980). Clinical and urodynamic assessment of alpha-adrenolytic therapy in patients with neurogenic bladder function. Paraplegia, 18, 229-238.

Jensen, D. (I98I). Uninhibited neurogenic bladder treated with Prazosin. Scand. F. Urol. Nephrol., 15, 229-233.

Kaplan, P. E. \& NanNinga, J. B. (1979). Reduction of bladder contractility after alpha adrenergic blockade and after ganglionic blockade. Acta Neurol. Scand., 59, 172-173.

KhanNa, O. M. P. (1976). Disorders of micturition. Neuropharmacological basis and results of drug therapy. Urology, 8, 316-328.

Kiruluta, G. H., Mercer, A. R. \& Winsor, G. M. (I98I). Prazosin as a cause of urinary incontinence. Urology, 18, 618-619.

Koyanagi, T., Arikado, K., Takamatsu, T. \& Tsudi, T. (I982). Relevance of sympathetic dyssinergya in the region of external urethral sphincter: possible mechanism of voiding dysfunction in the absence of (somatic) sphincter dyssinergya. F. Urol., 127, 277-282.

Migne, J., Saint-Maurice, J. P., Santonja, R. \& Kuntz, S. (I974). Activité anti-agrégant plaquettaire. Effets d'un alpha-bloqueur: la Nicergoline. Sem. Hop. Paris, 50, 649-655.

Mobley, D. F. (1976). Phenoxybenzamine in the management of neurogenic vesical dysfunction. F. Urol., I16, 737-738.

Nordling, J., Christensen, B. \& Gosling, J. A. (I980). Noradrenergic innervation of the human bladder in neurogenic dysfunction. Urol. Int., 35, I 88-193.

Pedersen, E., Torring, J. \& Klemar, B. (1980). Effect of the alpha-adrenergic blocking agent thymoxamine on the neurogenic bladder and urethra. Acta Neurol. Scand., 6i, IO7-I I4.

Pony, J. C., Bourdonnec, C., Amelot, J., Dallerac, J., Daubert, J. C. \& Gouffault, J. (1982). Etude hémodynamique de la Nicergoline. Ann. Cardiol. Angéiol., 3I, 67-70.

Ronchi, F., Maronato, A., Ceccardi, R., Rigatti, P. \& Sossini, B. M. (i982). Symptomatic treatment of bening prostatic obstruction with Nicergoline: a placebo controlled clinical study and urodynamic evaluation. Urol. Res., I0, I3 I-I34.

Rossier, A. N., Fam, B. A., Lee, L. Y., Sarkarati, M. \& Evans, D. A. (I982). Role of striated and smooth muscle components in the urethral pressure profile in traumatic neurogenic bladders: a neuropharmacological and urodynamic study. F. Urol., I28, 529-535.

ScotT, M. B. \& MoRrow, J. W. (1978). Phenoxibenzamine in neurogenic bladder dysfunction after spinal cord injury. I. Voiding dysfunction. F. Urol., II9, 480-482.

SCOTT, M. B. \& MORROW, J. W. (I978). Phenoxybenzamine in neurogenic bladder dysfunction after spinal cord injury. II. Autonomic dysrreflexia. F. Urol., I I9, 483-484.

Whitfield, H. N., Doyle, P. T., Mayo, M. E. \& Poopalasingham, N. (i 976). The effect of adrenergic blocking drugs on outflow resistance. Br. F. Urol., 47, 823-827. 